\title{
22. BOLBOFORMA FROM LEG 105, LABRADOR SEA AND BAFFIN BAY, AND THE CHRONOSTRATIGRAPHY OF BOLBOFORMA IN THE NORTH ATLANTIC1
}

\author{
Amy Pallant ${ }^{2}$ and Mike Kaminski ${ }^{3}$
}

\section{INTRODUCTION}

The genus Bolboforma, first described by Daniels and Spiegler (1974), is a problematic group of calcareous microfossils. Bolboforma is most probably a planktonic cyst (Rögl and Hochuli, 1976) having protozoan or algal affinities (Poag and Karowe, 1986). Its known distribution at present suggests that various species may have potential for becoming good stratigraphic indicators. Bolboforma also may be useful in areas where other calcareous planktonic microfossils are poorly preserved, i.e., the North Sea, the Norwegian-Greenland Sea, and Baffin Bay. This report summarizes the known occurrences of Bolboforma in the North Atlantic and correlates them with a standard geochronology (Berggren et al., 1985a, 1985b). In addition, further occurrences of Bolboforma are reported from Sites 645, 646, and 647 (Fig. 1).

\section{MATERIALS AND METHODS}

Samples from Sites 645,646 , and 647 were dried at $60^{\circ} \mathrm{C}$, boiled in a dilute solution of Calgon, and then washed on a $63 \mu \mathrm{m}$ sieve. The residues were dried and examined with a binocular microscope.

Information for Figures 2 and 3 was interpolated from existing reports (Echols, 1985; King, 1983; Müller et al., 1985; Murray, 1979, 1984, 1987; Poag and Karowe, 1986) and correlated to the Berggren time scale (Berggren et al., 1985a, 1985b). For DSDP Sites 403, 404, 406, $552,553,554,555,119,606,609 \mathrm{~B}, 610,611 \mathrm{C}$, and 400A, depth in meters below seafloor was determined for each sample, and the sedimentation-rate curve from the site chapters was used to determine the age in Ma. This age was then plotted for each occurrence. COST B-2, COST B-3, ASP15, and ASP22 data were compiled for DSDP Sites 106, 604, and 612 from Poag and Karowe (1986). Occurrences of Bolboforma could not be correlated with standard nannofossil zones for DSDP Sites $348,400,550$, and the North Sea wells (King, 1983); thus, ranges given are approximate ages and are represented in Figures 2 and 3 by dashed lines.

\section{DATA}

Bolboforma was found at all three Leg 105 sites. Bolboforma irregularis Daniels and Spiegler is present in Hole 647A from the Labrador Sea in Samples 105-647A-28R-4, 91-98 cm, and 105-647A-30R-3, 110-112 cm. Bolboforma metzmacheri (Clodius) is present in Hole 646B, also at the Labrador Sea, in Sample 105-646B-74X-4, 10-12 cm. The species also occurs sporadically in Hole 645E at Baffin Bay from Section 105-645E-36R, CC down to Section 105-645E-50R, CC, where it is most common in Sample 105-645E-38R-6, 127-129 cm. A list of samples that yielded $B$. metzmacheri in Hole $645 \mathrm{E}$ follows:

\footnotetext{
${ }^{1}$ Srivastava, S. P., Arthur, M. A., Clement, B., et al., 1989. Proc. ODP, Sci. Results, 105: College Station, TX (Ocean Drilling Program).

2 Department of Geology and Geophysics, Woods Hole Oceanographic Institute, Woods Hole, MA 02547.

${ }^{3}$ WHOI/MIT Joint Program in Oceanography, Woods Hole Oceanographic Institute, Woods Hole, MA 02547.
}

\begin{tabular}{|c|c|}
\hline Core/sectio & $\begin{array}{c}\text { Interval } \\
\text { (cm) }\end{array}$ \\
\hline 105-645E-38R-6 & $127-129$ \\
\hline \multicolumn{2}{|l|}{$105-645 E-38 R, C C$} \\
\hline $105-645 E-44 R-2$ & $96-99$ \\
\hline $105-645 R-44 R-2$ & 115 \\
\hline 105-645E-46R-3 & 95-97 \\
\hline \multicolumn{2}{|l|}{$105-645 \mathrm{E}-48 \mathrm{R}, \mathrm{CC}$} \\
\hline $105-645 E-48 R-2$ & $84-86$ \\
\hline 105-645E-49R-2, & $120-122$ \\
\hline $105-645 E-49 R-3$ & $62-64$ \\
\hline 105-645E-50R-2 & $84-86$ \\
\hline \multicolumn{2}{|l|}{ 105-645E-50R, CC } \\
\hline $105-645 E-53 R-3$ & $101-103$ \\
\hline 105-645E-53R, CC & \\
\hline
\end{tabular}

Bolboforma species A and B, as yet undescribed, were observed in Hole 646B in Samples 105-646B-71X-2, 60-62 cm, and 105-646B-74X-4, 60-62 cm.

\section{DISCUSSION}

Little is known about the chronostratigraphy of different species of Bolboforma in the North Atlantic. What is known from the literature is summarized in Figures 2 and 3. Here, we applied a standard biochronological framework, the Berggren time scale (Berggren et al., 1985a, 1985b), to all reported occurrences of species in DSDP sites from the North Atlantic, as well as those from ODP Leg 105. For each citation in the literature, we determined the age and zonal assignment from either the sediment-rate curve of the respective DSDP site chapters or from analogous time charts in reports by King (1983), Müller et al. (1985), and Poag and Karowe (1986). Stratigraphic ranges of Bolboforma species that could not be correlated with standard nannofossil zones are reported according to our estimates. Thus, our charts present standardized systematic ranges of the North Atlantic species of Bolboforma (Figs. 2 and 3).

From Figures 2 and 3, one can see that many species have long ranges, but most species occur in the Miocene. From the limited data available, we found that the geographic distribution of the genus as well as the occurrence of several species is widespread in the Miocene. Bolboforma aculeata Daniels and Spiegler has the most restricted range in the North Atlantic and may be useful for determining the upper Miocene. Bolboforma costata Murray appears to be restricted to upper Pliocene. With the growing knowledge of distribution of these taxa, furthur studies may eventually lead to a zonation based on Bolboforma.

Because of their small size, species of Bolboforma are often found in muddy sediments and may be preferentially concentrated in high-latitude, contourite drift deposits (Murray, 1984). Bolboforma metzmacheri (Clodius) was found in Hole 646B just below seismic reflector R3 (Srivastava, Arthur, et al., 1987). Kaminski et al. (this volume) interpreted this seismic horizon to represent the initiation of the Denmark Straits overflow from 


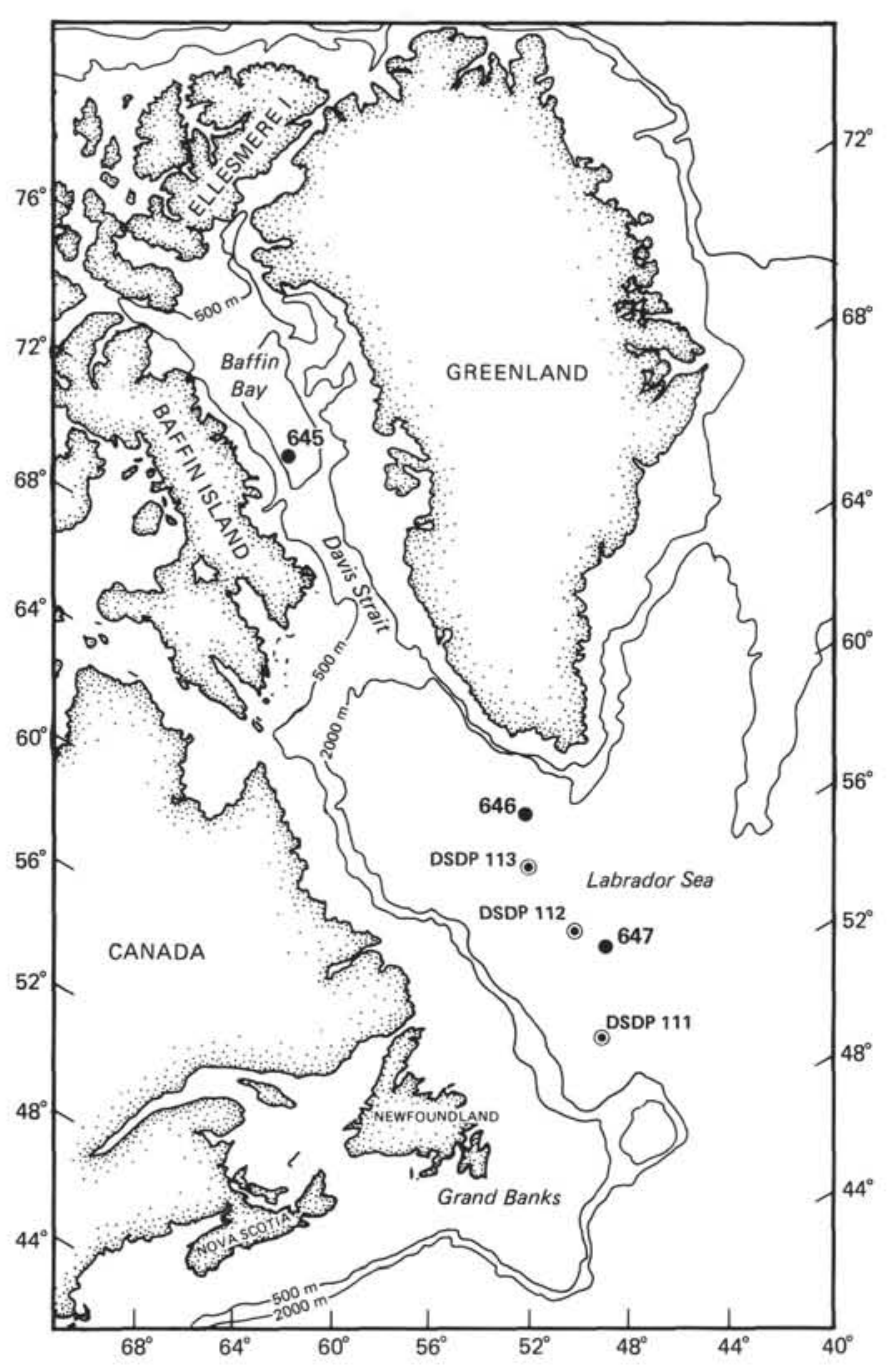

Figure 1. Generalized bathymetry of the Labrador Sea-Baffin Bay region showing exploratory wells, DSDP sites, and Leg 105 Sites 645, 646, and 647 .

the Norwegian-Greenland Sea, which corresponds to an increase in sedimentation rates at the site. This implies that preservation is not limited to sediment types but in some way reflects paleoenvironmental controls. Bolboforma is probably a planktonic cyst (Rögl and Hochuli, 1976). Such cysts are produced during periods of ecological adversity; they are usually deposited in shallow and deep basins and seem to prefer cool water (latitudes higher than $25^{\circ}$ to $35^{\circ}$ ), according to their known regional distribution. If periods of adversely low surface-water temperatures are the controlling influences, then abundance and diversity might be highest in high latitudes.

Bolboforma species are very resistant to dissolution, as indicated by their excellent preservation in samples that contain strongly etched and broken planktonic foraminifers (i.e., as in DSDP Cores 550-17 and 550-18). In Hole 645E and in Norwegian-Greenland Sea Cores 348-27 and 348-30, these species are the only preserved calcareous microfossils (Müller et al., 1980). Because planktonic foraminifer preservation in the Miocene of Site 645 was poor, Bolboforma may be the only key for correlating this site with the North Atlantic. In addition, the temporal occurrences of Bolboforma metzmacheri (Clodius) in the North Sea and Baffln Bay areas may be causally related. This could imply either concurrent geographic development of populations or advection of specimens by a proto-West Greenland current into Baffin Bay.

\section{TAXONOMY}

Bolboforma sp. A, Pl. 1, Fig. 2.

Description. Monocamerate. Test is ornamented with well-defined, subcontinuous, flat-bladed ridges arranged radially around the aperture. Small perpendicular secondary ridges connect the radial ridges. Aperture is circular and produced on a small neck.

Occurrence. Upper Miocene, Zone NN11.

Type locality. Labrador Sea, ODP Site 646.

Bolboforma sp. B, Pl. 1, Fig. 3.

Description. Test is small, monocamerate, and has a slightly flattened aberal end. Ornamentation consists of closely spaced, nonbifurcating spines located on irregular ridges. Ridges are interconnected in a quasireticulate pattern. Aperture is circular, well-defined, and at the end of a produced neck. Neck is smooth.

Occurrence. Upper Miocene, Zone NN11.

Type locality. Labrador Sea, ODP Site 646.

\section{ACKNOWLEDGMENTS}

This study was supported through grants from the Texas A\&M Research Foundation/U.S. Scientific Program, Grant 1892-B05 to MAK. This is a contribution of the Deep Water Benthic Foraminifer Project, which is conducted by W. A. Berggren and colleagues at the Woods Hole Oceanographic Institution and is sponsored by a consortium of oil companies.

We thank the Ocean Drilling Program for the opportunity to participate during Leg 105 and for providing samples. W. A. Berggren, C. W. Poag, and S. R. Srivastava kindly reviewed the manuscript (contribution No. 6489 of the Woods Hole Oceanographic Institution).

\section{REFERENCES}

Berggren, W. A., Kent, D. V., and Flynn, J. J., 1985a. Paleogene geochronology and chronostratigraphy. In Snelling, N. J. (Ed.), The Chronology of the Geological Record: London (Blackwell Scientific Publications), Geol. Soc. London Mem. 10:141-195.

Berggren, W. A., Kent, D. V., Van Couvering, J. A., 1985b. Neogene geochronology and chronostratigraphy. In Snelling, N. J. (Ed.), The Chronology of the Geological Record: London (Blackwell Scientific Publications), Geol. Soc. London Mem. 10:211-259.

Echols, D. J., 1985. "Bolboforma": a Miocene algae(?) of possible biostratigraphic and paleoclimatic value. In Bougault, H., Cande, S. C., et al., Init. Repts. DSDP, 82: Washington (U.S. Govt. Printing Office), 605-610.

King, C., 1983. Cainozoic micropaleontological biostratigraphy of the North Sea. Rept. Inst. Geol. Sci., 82(7).

Müller, C., Spiegler, D., and Pastouret, L., 1985. The genus Bolboforma Daniels and Europe. In de Graciansky, P.C., Poag, C. W., et al., Init. Repts. DSDP, 80(Pt. 1): Washington (U.S. Govt. Printing Office), 669-675.

Murray, J. W., 1979. Cenozoic biostratigraphy and paleoecology of Sites 403 to 406 based on the foraminfers. In Montadert, L., Roberts, D. G., et al., Init. Repts. DSDP, 48: Washington (U.S. Govt. Printing Office), 415-430.

Murray, J. W., 1984. Biostratigraphic value of Bolboforma, Leg 81, Rockall Plateau. In Roberts, D. G., Schnitker, D., et al., Init. Repts. $D S D P, 81$ : Washington (U.S. Govt. Printing Office), 535-539.

Murray, J. W., 1987. Bolboforma from North Atlantic sites, Deep Sea Drilling Project Leg 94. In Ruddiman, W. F., Kidd, R. B., Thomas, E., et al., Init. Repts. DSDP, 94: Washington (U.S. Govt. Printing Office), 813-814.

Poag, C. W., and Karowe, A. L., 1986. Stratigraphic potential of Bolboforma significantly increased by new finds in the North Atlantic and South Pacific. Palios, 1:162-171.

Rögl, F., and Hochuli, P., 1976. The occurrence of Bolboforma, a probable algal cyst, in the antarctic Miocene of DSDP Leg 35. In Hollister, C. D., Craddock, C., et al., Init. Repts. DSDP, 35: Washington, (U.S. Govt. Printing Office), 713-719.

Date of initial receipt: 6 July 1987

Date of acceptance: 11 January 1988

Ms 105B-172 


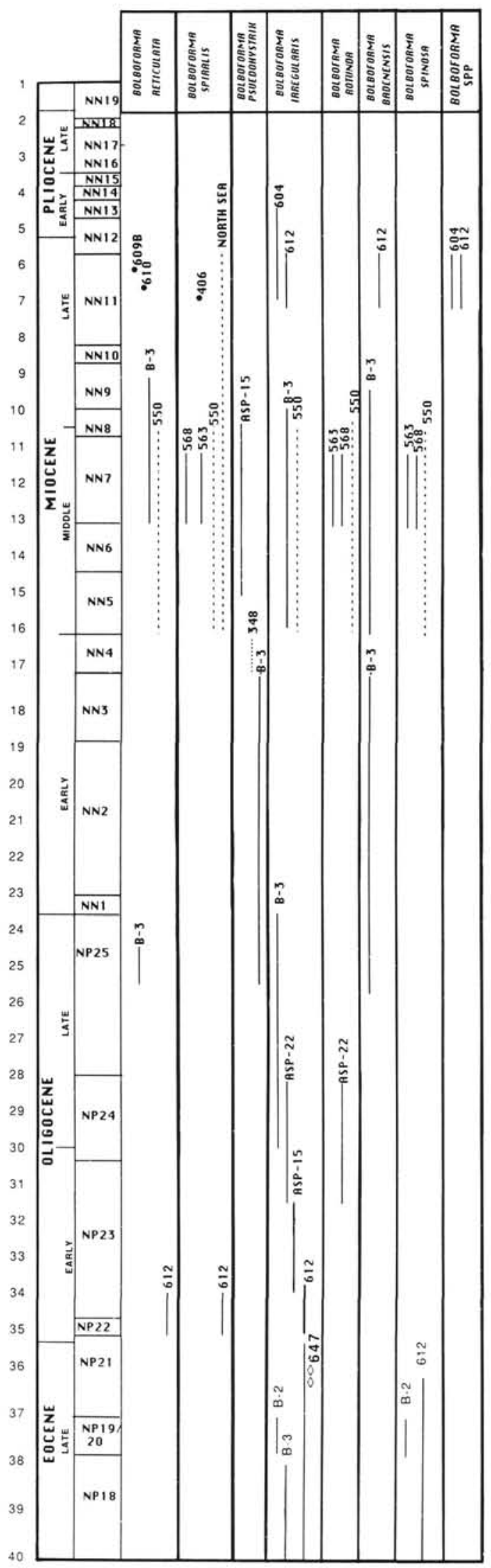

Figure 2. Distribution of Neogene species of Bolboforma in the North Atlantic. Dashed lines represent approximate ranges for those species not correlated with the Berggren et al. time scale (1985a, 1985b). Solid lines indicate continuous ranges. Dots are single occurrences. 


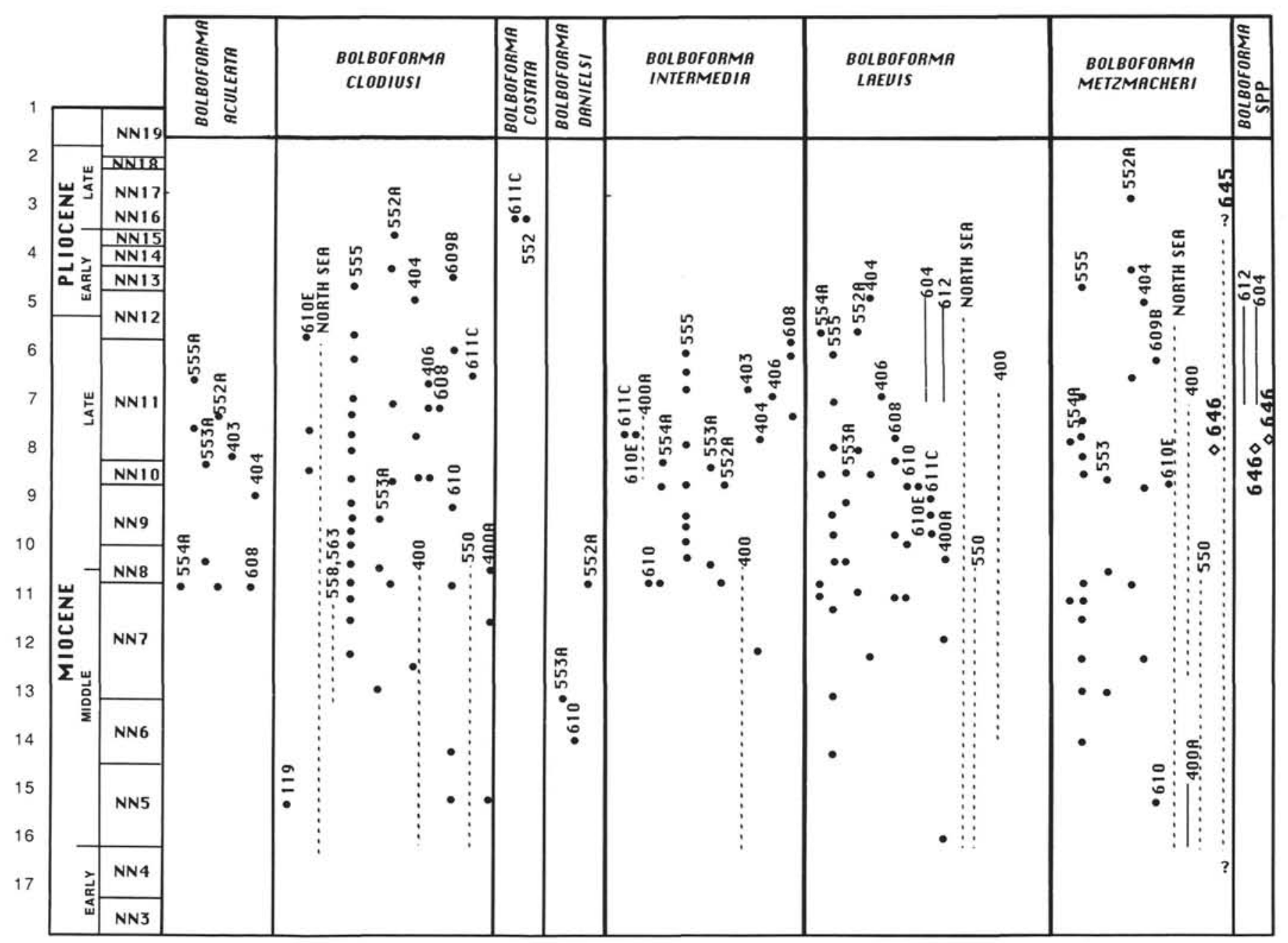

Figure 3. Distribution of Paleogene to Neogene species of Bolboforma in the North Atlantic. Dashed lines represent approximate ranges for those species not correlated with the Berggren et al. time scale (1985a, 1985b). Solid lines indicate continuous ranges. Dots are single occurrences. 


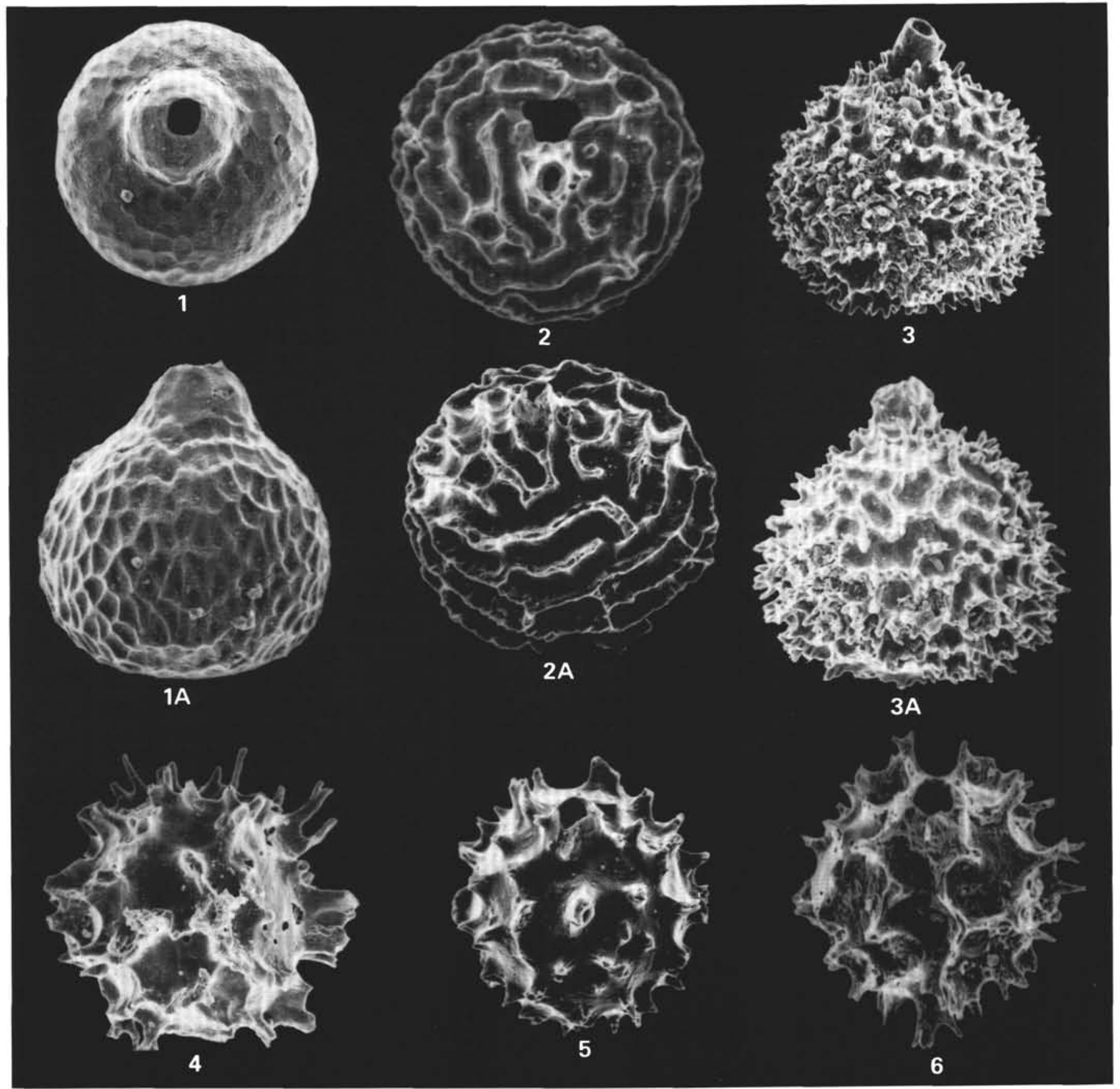

Plate 1. Species of Bolboforma. 1, 1a. Bolboforma metzmacheri (Clodius) $\times 600$, Sample 105-646-74X-4, 10-12 cm. 2, 2a. Bolboforma sp. A, $\times 600$, monocamerate, flattened, bladed ridges; Sample 105-646-74X-4, 10-12 cm. 3, 3a. Bolboforma sp. B, $\times 600$, monocamerate, spinose, irregular ridges; Sample 105-646-71X-2, 60-62 cm. 4 and 5. Bolboforma irregularis Daniels and Spiegler, $\times 600$, Sample 105-647-28R-4, 91-98 cm. 6. Bolboforma irregularis Daniels and Spiegler, $\times 600$; Sample 105-647-30R-3, 110-112 cm. 